\title{
Impact of social relationships on Alzheimer's memory impairment: mechanistic studies
}

\author{
Ya-Hsin Hsiao, Chih-Hua Chang and Po-Wu Gean ${ }^{*}$
}

\begin{abstract}
Alzheimer's disease (AD) is characterized by progressive memory and neuronal loss culminating in cognitive impairment that not only affects a person's living ability but also becomes a society's as well as a family's economic burden. AD is the most common form of dementia in older persons. It is expected that the number of people with AD dementia will increase dramatically in the next 30 years, projecting to 75 million in 2030 and 131.5 million in 2050 worldwide. So far, no sufficient evidence is available to support that any medicine is able to prevent or reverse the progression of the disease. Early studies have shown that social environment, particularly social relationships, can affect one's behavior and mental health. A study analyzing the correlation between loneliness and risk of developing AD revealed that lonely persons had higher risk of $A D$ compared with persons who were not lonely. On the other hand, it has been reported that we can prevent cognitive decline and delay the onset of $A D$ if we keep mentally active and frequently participate in social activities. In this review, we focus on the impact of social behaviors on the progression of cognitive deficit in animal models of AD with a particular emphasis on a mechanistic scheme that explains how social isolation exacerbates cognitive impairment and how social interaction with conspecifics rescues AD patients' memory deficit.
\end{abstract}

Keywords: Alzheimer's disease, Social isolation, Hippocampus, Cognition, Epigenetic, BDNF, Neurogenesis

\section{Background}

An early sign of Alzheimer's disease (AD) is frequent forget of recently happened events, which culminates in cognitive impairment that not only affects a person's living ability but also becomes a society's as well as a family's economic burden. AD is the most common form of dementia in aged persons [1-3]. It was estimated that there were 5 million individuals with AD dementia in 2010 in the USA. The number will increase dramatically in the next 30 years, projecting to be 16 million according to the Alzheimer's association report (2017). In histopathological examination, AD is typically characterized by two biomarkers: neuritic plaques consisting of amyloid beta $(A \beta)$ peptide, and neurofibrillary tangles consisting of hyperphosphorylated tau protein $[4,5]$. Accumulating evidence indicates that plaques and neurofibrillary tangles are caused by glial activation, neuritic dystrophy and loss of synapses, and neuron death [6]. Currently, no particular

\footnotetext{
* Correspondence: powu@mail.ncku.edu.tw

Department of Pharmacology, College of Medicine, National Cheng Kung University, No.1, Ta-Shieh Rd, Tainan City 701, Taiwan
}

medicine has been definitely shown to be able to prevent or reverse the progression of AD [7]. Previous studies suggest that the brain levels of $A \beta$ are correlated with and may be the cause of memory deficit in patients developing $\mathrm{AD}[8,9]$. The amyloid precursor protein (APP) is an integral membrane protein that the $A \beta$ is derived from. [10]. APP can be cleaved by $\beta$-secretase and $\gamma$-secretase at the $\mathrm{N}$ and $C$ termini to yield $A \beta$, which is released into the extracellular space $[11,12]$. The precise mechanisms by which $A \beta$ impairs synaptic plasticity and induces memory deficit are not fully understood. $A \beta$-induced endocytosis of synaptic NMDA receptors $[13,14]$ and AMPA receptors [15], decrease in dendritic spines and disruption of the cytoskeletal network [16], activation of protein (STEP) [17-19], and disruption of neuronal glutamate uptake [20] in the affected brain regions could be the underlying mechanisms.

Mild cognitive impairment (MCI) causes a slight decline in cognitive abilities but the decline is not sufficient to interfere with daily activities [21]. People with MCI are more likely to develop $\mathrm{AD}$ or other dementias at a 
rate of approximately $10 \%$ to $15 \%$ per year [22, 23]. However, MCI does not always progress to dementia. In clinical trials, it has been repeatedly demonstrated that cognitive function can be improved in elders including AD patients after physical exercise training [24, 25]. In contrast, medical conditions such as high blood pressure, hypercholesterol, mental illness, and lifestyle factors like infrequent physical exercise and seldom social activity may aggravate cognitive decline. It is thus advised that people seek help from medical doctor for diagnosis and possible treatment when they begin to experience difficulty in recollection. In this review, we focus mainly on the impact of social behaviors on the progression of cognitive impairment in the animal model of AD.

\section{Factors that regulate Alzheimer patients' cognitive impairment}

Early studies have shown that social environment, particularly social relationships, can affect one's behavior and mental health [26]. A longitudinal cohort study analyzing the correlation between loneliness and the risk of developing $\mathrm{AD}$ revealed that persons who were living lonely had higher risk of AD compared with persons who were not [27]. Unexpectedly, brain autopsy showed that loneliness score was not correlated with $A \beta$ immunoreactive plaques and cerebral infarction, arguing against the direct contribution of social isolation to the risk of $\mathrm{AD}$ and the underlying mechanism is unrelated to $\mathrm{AD}$ pathology [27]. In contrast, a later study using the Pittsburgh Compound B (PiB)-PET criteria to measure fibrillary amyloid burden revealed a correlation between loneliness and elevated cortical amyloid in cognitively normal older adults, suggesting that loneliness is a risk factor relevant to preclinical AD [28]. Thus, the neurobiological mechanisms underlying memory decline associated with social isolation remain elusive.

Social isolation, the absence of interaction with others, is considered the major source of mental and psychosocial stress, which contributes to the increased prevalence of neurological diseases [29]. It also increases the risk of morbidity and mortality as well as the onset of many neuropsychological disorders [29-32]. In rodents, it has been repeatedly demonstrated that social isolation exacerbates memory deficit in the animal model of $\mathrm{AD}$ $[33,34]$. The mechanisms mediating this impairment are not yet completely understood but may include the production of $A \beta$ peptide and the phosphorylation of tau protein $[35,36]$, an increase in oxidative stress and inflammatory reaction [37] accompanied by inhibition of anti-inflammatory responses [38], synaptic plasticity including the reduction of brain-derived neurotrophic factors (BDNF) [39, 40], and myelination [41]. Social isolation may also decrease hippocampal BDNF gene $\mathrm{H} 3$ acetylation and BDNF protein expression [42]. Consistently, social isolation-induced anxiety- and autism-like behaviors are lessened by hippocampal BDNF overexpression [43]. However, contrast results have been reported in the female mouse brain in which social isolation-induced anxiety-like behavior is mediated by the upregulation of mRNA and protein levels of BDNF in the cerebral cortex [44]. Sex difference in response to stress or brain region difference (cerebral cortex vs. hippocampus) may account for the differential results. Finally, social isolation-induced aggression-related disorders are reversed by combined treatment with antidepressant fluoxetine plus re-socialization that is able to restore BDNF expression through epigenetic regulation [45].

We have studied the cellular mechanisms of how social isolation aggravates $\mathrm{AD}$-associated memory decline in APP/PS1 mice. We first constructed age-dependent memory performance using a contextual fear conditioning paradigm and demonstrated that the memory of APP/PS1 mice is normal at 3 months of age and begins to declines at 6 months. However, APP/PS1 mice reared in socially isolated cages exhibited memory deficit as early as 3 months of age, which was associated with increases in hippocampal $A \beta$, calpain activity, and p25/p35 ratio concomitant with decreases in membrane-associated p35, GluR1, and GluR1 Ser831 phosphorylation, and surface $\alpha$ amino-3-hydroxy-5-methyl-4-isoxazolepropionic acid receptors (AMPARs) [36]. We conducted immunoprecipitation experiments using antibody against p35 and found that $\alpha$-CaMKII, GluR1, and PSD-95 were associated with p35. Reciprocal immunoprecipitations using antibodies against $\alpha$-CaMKII, GluR1, and PSD-95 confirmed these molecules were associated with p35. Thus, it is proposed that social isolation facilitates memory decline by increasing the $A \beta$ level and calpain activity, subsequently leading to the conversion of p35 to p25 and decreased association of p35, $\alpha$-CaMKII, and GluR1, resulting in the endocytosis of AMPA receptors (Fig. 1).

Exercise regularly and eat a healthy diet rich in fruits and vegetables are known to be beneficial for preventing cognitive decline with aging and AD. Exercise may induce biochemical changes in the brain areas important for learning and memory such as hippocampus and related medial temporal lobe circuitry [46]. Current evidence from multi-country ecological and observational studies suggests that the traditional Mediterranean diet is a model of healthy eating in terms of the reduced incidence of cardiovascular and chronic degenerative diseases. The Mediterranean diet is composed of abundant fruits, vegetables, breads, other forms of cereals, potatoes, beans, nuts, and seeds. In contrast, the Western dietary pattern, with large amounts of meat, is highly correlated with the risk of developing $\mathrm{AD}[47,48]$. 


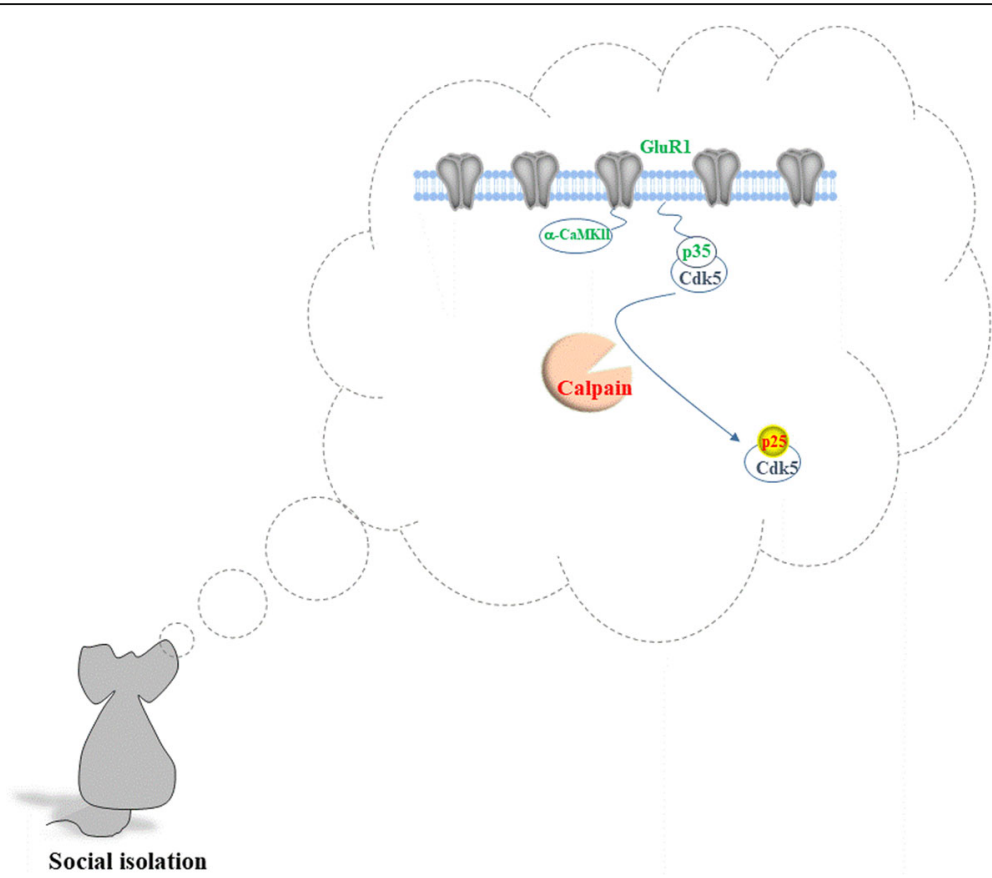

Fig. 1 Schematic diagram illustrates how social isolation exacerbates memory decline in APP/PS1 mice. We propose that social isolation increases calpain activity leading to conversion of p35 to p25. Decrease in membrane associated p35 reduces a-CaMKII synaptic distribution resulting in the synaptic removal of AMPARs

A previous study showed that social stress activated the sympathetic nervous system and increased bone marrow production of immature proinflammatory monocytes, which could be blocked by $\beta$-adrenoreceptor antagonists [37]. Social isolation also increased superoxide-producing nicotinamide adenosine dinucleotide phosphate (NADPH) oxidase 2 (NOX2) expression and immunoreactive microglia [9]. Social isolation-induced behavioral and histopathological changes were ameliorated by administration of antioxidant/NOX inhibitor apocynin, suggesting that increased oxidative stress underlay the adverse effects of social isolation $[34,49,50]$. Consistent with these results, in APP/PS1 mice, we found that $\gamma$-secretase activity and levels of $A \beta-40$ and $A \beta-42$ were elevated in socially isolated mice compared to those of mice in group housing. $\mathrm{N}$-acetylcysteine (NAC) is a potent antioxidant which has been demonstrated to protect the brain from focal cerebral ischemia [50]. Chronic treatment of mice with NAC reversed the elevated $\gamma$-secretase activity and $A \beta-40$ and A $\beta-42$ levels in isolated APP/PS1 mice [51]. It is likely that NAC's antioxidant effect counteracts social isolationinduced oxidative stress (50), increased $\gamma$-secretase activity and $A \beta$ levels $[52,53]$.

\section{Social interaction rescues Alzheimer patients' memory} deficit by increasing BDNF expression

BDNF produces many beneficial effects on brain functions. For example, it increases synaptic plasticity and enhances neurogenesis and cognitive functions [54]. In contrast, decreased BDNF and its receptor tropomyosinrelated kinase $B(\operatorname{TrkB})$ contribute to cognitive decline in aging $[55,56]$. The levels of serum BDNF in patients with drug-naïve first episode depressive disorder were significantly lower as compared to healthy controls [57]. Reduced protein and mRNA levels of BDNF were found in the hippocampus of postmortem $\mathrm{AD}$ samples and MCI patients, [58-60]. In aged rats and primates, BDNF infusion produced beneficial effects on age-related perturbations in gene expression and ameliorated agerelated cognitive impairment [61]. Furthermore, systemic administration of a small-molecule TrkB agonist, 7,8dihydroxyflavone (7,8-DHF), in amyloid precursor protein (APP) transgenic mice improved their synaptic loss and memory deficit [62-65].

Clinicians and medical reports often advise us that one can reduce the risk of cognitive rundown and delay the onset of $\mathrm{AD}$ if one maintains strong social connections $[66,67]$. Indeed, a relationship between frequent social activities and better cognitive function has been established [66-68]. However, the mechanisms behind social and emotional influence are largely unknown. We investigated the hypothesis that having a company may produce a beneficial effect on the cognitive function in $\mathrm{AD}$ mice. Indeed, the results showed that APP/PS1 mice performed better in memory tasks if their companies interacted with them more often. 
Experience-induced changes in dendritic spine stability serve as the mechanism for the maintenance of long term memories. We found that co-housing-induced improvement of memory in the AD mice was accompanied by an increase in spine density in the hippocampus (Fig. 2). Furthermore, we demonstrated that the beneficial effect of co-housing was mediated by increased BDNF expression and subsequent neurogenesis in the dentate gyrus (DG) of the hippocampus [65].

These results are consistent with recent cohort studies. Among 3294 participants controlled for age and sex, Salinas et al. found that participants with more companionship had higher serum BDNF level and reduced risk for dementia [69]. Similar results were observed in rodents that had been reared in a communal nest $(\mathrm{CN})$, a form of early social enrichment. These mice showed higher BDNF levels in the brain [70].

It is known that hippocampal BDNF modulates neurogenesis, synaptic plasticity, and behaviors in rodents [71-73]. Hippocampal neurogenesis can be regulated by environmental factors such as environmental enrichment and exercise [74]. For example, exercise improves social isolation-induced impairment of cognitive performance and reduction of hippocampal BDNF [75]. Rodents housing with a running wheel over a six-month period [76] and exercise [77] can partially reversed agedependent reduction in neurogenesis and cognition.

To investigate whether neurogenesis in the hippocampus plays a critical role in cohousing-induced reversal of cognitive decline in APP/PS1 mice, the cell proliferation blocker methylazoxymethanol acetate (MAM) was used [78]. We found that blocking neurogenesis in the hippocampal DG prevented cohousing-induced rescue of memory impairment in APP/PS1 mice [65].

We further investigated the role of newborn neurons in cohousing-induced reversal of memory decline. A retrovirus vector encoding diphtheriatoxin receptor (DTR) was injected into the dentate gyrus to tag and target mitotic neurons for subsequent ablation [79, 80].
When diphtheriatoxin (DT) was bound to the receptor, mitotic neurons with DTR underwent apoptotic cell death. Administration of DT significantly reduced BrdU ${ }^{+} / \mathrm{NeuN}^{+}$cells in the DG and the improvement of memory after cohousing was abolished. These results suggest that neurogenesis in the hippocampal DG is required for the rescue of memory impairment in APP/PS1 mice.

\section{Epigenetic regulation of BDNF expression by social interaction}

Epigenetic mechanisms refer to regulatory modifications of gene expression without changing gene sequence [81-83]. Such effects provide an organism with the molecular mechanisms to promptly adapt to environmental changes as well as to regulate diverse biological processes [84] with stable alterations in gene expression. Epigenetic modifications are commonly regulated by chromatin remodeling via histone acetylation, or by direct methylation of DNA. Chromatin remodeling through histone-tail acetylation alters the compact chromatin structure and enables the transcriptional machinery to access the transcriptional start site $[85,86]$. Conversely, histone deacetylases (HDACs) repress transcription by condensing the chromatin via removing acetyl groups from core histone proteins. HDAC proteins are classified into four classes based on three-dimensional structures, substrate specificity and DNA sequence homology to the yeast original enzymes. Classes I, II, and IV belong to classical HDACs and their activities are inhibited by trichostatin A (TSA), whereas Class III HDACs are a family of NAD ${ }^{+}$-dependent proteins having sequence similarity to the yeast Sir2 protein [87]. HDAC2, a Class I HDAC, is localized to the promoters of numerous synaptic plasticityassociated genes, including $B d n f$ promotor IV, where it deacetylates histone substrates and negatively regulates gene transcription $[88,89]$. Consequently, knockdown of HDAC2 or treatment with HDAC inhibitor promotes synaptic gene expression, long-term synaptic plasticity, and memory retention [88-91].
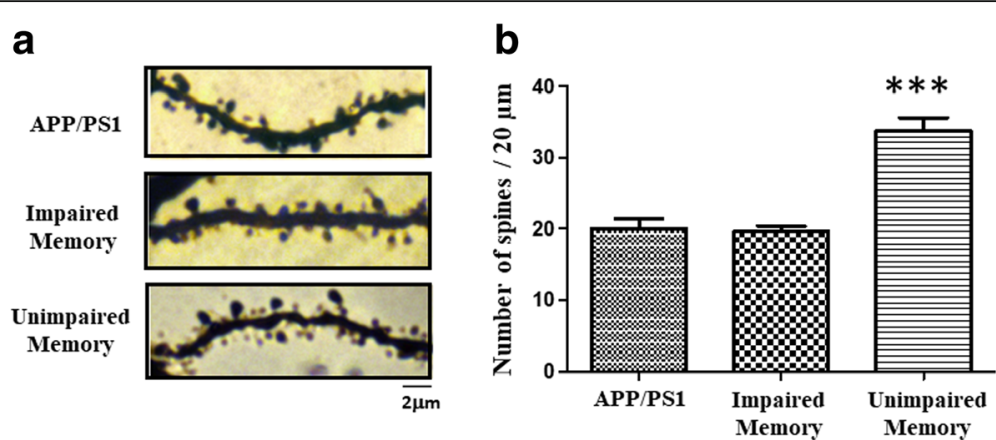

Fig. 2 Co-housing with conspecific increases spine density in hippocampal CA1 neurons of the AD mice. Representative images (a) and statistical analyses of Golgi staining (b) from the hippocampal CA1 neurons of the control, memory-unimproved and memory-improved AD mice after cohousing with conspecific. ${ }^{* * *} p<0.001$ vs. memory-unimproved 
Voluntary wheel running and environmental enrichment have been shown to increase BDNF gene expression in the hippocampus of rodents [92-97]. The mouse BDNF gene contains multiple $5^{\prime}$ noncoding exons and a single 3' coding exon (exon IX) for the BDNF protein [98]. The noncoding exons undergo alternative splicing and join exon IX to produce multiple exon-specific BDNF transcripts for fine-tuning transcription in different cell types and by different neuronal activities. Previous studies have shown that exercise stimulates DNA demethylation by inducing methyl-CpG-binding protein 2 (MeCP2) phosphorylation resulting in the dissociation of phospho-MeCP2 from the $B d n f$ promoter, and leading to $B d n f$ transcription in the rat hippocampus [99]. In addition, the chromatin immunoprecipitation assay revealed that exercise increased histone $\mathrm{H} 3$ acetylation and reduced mRNA and protein levels of HDAC5. Similarly, a marked increase in the BDNF mRNA in the hippocampus was observed in mice housed in an enriched environment for 3-4 weeks. Correspondingly, the enriched environment reduced histone $\mathrm{H} 3$ lysine 9 (H3K9) trimethylation at the BDNF P4 promoter and histone H3 lysine 27 (H3K27) trimethylation at the BDNF P3 and P4 promoters, leaving histone methylases and demethylases expression in the hippocampus untouched [100].

Postmortem studies reported that BDNF expression is lower in AD patients [57, 101]. Infusion of amyloid fibrils significantly increased HDAC2 expression and its occupancy in the promoter region of $B d n f$ exon IV, resulting in histone $\mathrm{H} 3$ deacetylation and the suppression of BDNF expression [102, 103]. We examined epigenetic changes in the mouse hippocampus that accompanied cohousing-induced memory improvement. We found that the level of HDAC2, but not that of HDAC1, was significantly lower in the memoryimproved mice than in the control and memoryunimproved APP/PS1 mice after cohousing. Knockdown of $\mathrm{Hdac} 2$ resulted in a higher freezing response after cohousing. Conversely, over-expression of HDAC2 blocked cohousing-induced memory improvement. The level of $B d n f$ exon IV mRNA increased significantly after knockdown of Hdac2. The ChIP assay revealed a decreased occupancy of HDAC2 in the promoter region of $B d n f$ exon IV of memory-improved mice but not memoryunimproved and control APP/PS1 mice. Consistently, the acetylation of histone 3 on Lys 9 (H3K9) and histone 4 on Lys12 (H4K12) increased significantly in the promoter region of $B d n f$ exon IV [104]. These results suggest that HDAC2 expression is reduced after cohousing that results in a decreased occupancy of HDAC2 and increased histone H3K9 and H4K12 acetylation in the promoter region of $B d n f$ exon IV. This leads to increased BDNF expression in the hippocampus and improves memory (Fig. 3). Further support for this notion comes from a study by Yamakawa et al., who investigate proteins that mediate HDAC2 recruitment to synaptic plasticity genes using an integrative genomics approach

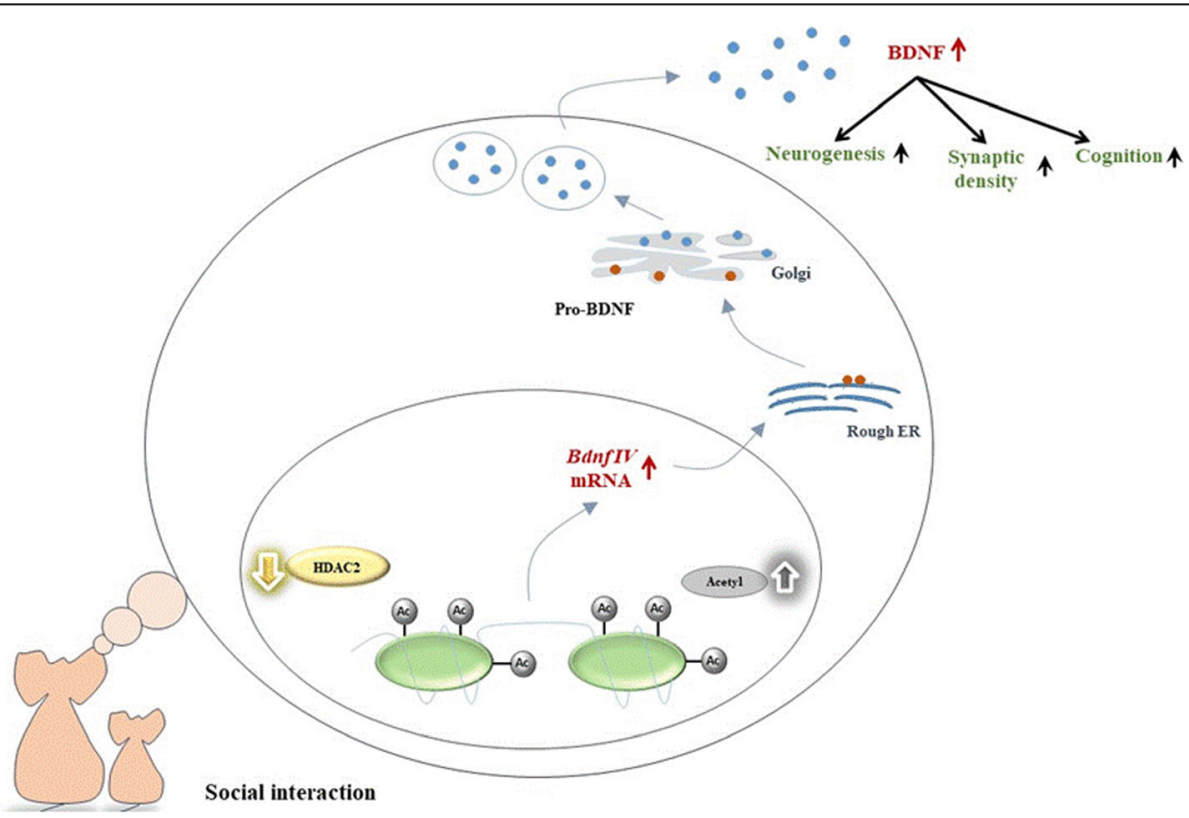

Fig. 3 Schematic diagram illustrates how co-housing reverses memory decline in APP/PS1 mice. We propose that co-housing reduces HDAC2 expression and the occupancy of HDAC2 in the promoter region of Bdnf exon IV resulting in the increased levels of acetylated histone H3K9 and H4K12. This leads to the higher transcription and translation of BDNF mRNA and protein in the hippocampus that improves memory. (Modified from reference [65]) 
[105]. They have demonstrated that Sp3 and HDAC2 interacts to repress gene expression and negatively regulates synaptic plasticity.

It is noted that, besides BDNF, the neurotrophin family also comprises nerve growth factor (NGF), neurotrophin 3 (NT3), and neurotrophin 4/5 (NT4/5) [106]. In nucleus basalis of Meynert, decreased NGF level has been shown to be associated with neurodegeneration of $\mathrm{AD}$ and treatment with NGF improved cognitive performance [107]. In addition, NGF gene therapy trials using NGF-grafted autologous fibroblasts increased neuronal responses in AD patients [108]. Therefore, epigenetic regulation of NGF expression by social interaction warrants further investigation.

\section{Conclusion}

Accumulating evidence suggests that both humans and mice have a higher risk of developing $\mathrm{AD}$ if they are lonely or living isolated. One mechanism can be accounted by the social stress-induced increased $A \beta$ and calpain activity which leads to conversion of p35 to p25 and decreased association of p35, $\alpha$-CaMKII, and GluR1, resulting in the removal of AMPA receptors from synaptic membrane. In contrast, AD mice can improve cognitive function if they are accompanied and interacted with conspecifics. Reduction in the level of HDAC2 as well as decreased occupancy of HDAC2 in the promoter region of $B d n f$ exon IV is likely the underlying mechanism. Consistently, HDAC inhibitor treatments and direct HDAC2 knockdown are able to recover impaired cognitive functions in the $\mathrm{AD}$ mice. Thus, targeting HDAC2 or inhibiting HDAC2-Sp3 binding can be a potential strategy against $\mathrm{AD}$ development.

\section{Acknowledgements}

We thank Dr. Chun-Lin Su for suggestions of experiments and comments of the manuscript.

\section{Funding}

This study was supported by the National Health Research Institute (grant NHRI-EX101-10117NI) and the Ministry of Science and Technology of Taiwan (grant MOST104-2321-B-006-029).

\section{Availability of data and materials}

Not applicable.

\section{Authors' contributions}

$\mathrm{YHH}$ and PWG contributed and wrote the first draft of this review. $\mathrm{YHH}$ and $\mathrm{CHC}$ contributed additional materials and made revisions. All authors read and approved the final manuscript.

\section{Ethics approval and consent to participate}

Not applicable

\section{Consent for publication}

Not applicable

\section{Competing interests}

The authors declare that they have no competing interests.

\section{Publisher's Note}

Springer Nature remains neutral with regard to jurisdictional claims in published maps and institutional affiliations.

Received: 13 October 2017 Accepted: 2 January 2018

Published online: 11 January 2018

\section{References}

1. Tiraboschi P, Hansen LA, Thal $L$, Corey-Bloom J. The importance of neuritic plaques and tangles to the development and evolution of AD. Neurology. 2004:62:1984-9.

2. Hebert LE, Weuve J, Scherr PA, Evans DA. Alzheimer disease in the United States (2010-2050) estimated using the 2010 census. Neurology. 2013;80: 1778-83.

3. Todd S, Barr S, Roberts M, Passmore AP. Survival in dementia and predictors of mortality: a review. Int J Geriatr Psychiatry. 2013;28:1109-24.

4. Glenner GG, Wong CW. Alzheimer's disease: initial report of the purification and characterization of a novel cerebrovascular amyloid protein. Biochem Biophys Res Commun. 1984;120:885-90.

5. Grundke-lqbal I, lqbal K, Tung YC, Quinlan M, Wisniewski HM, Binder LI. Abnormal phosphorylation of themicrotubule-associated protein tau (tau) in Alzheimer cytoskeletal pathology. Proc Natl Acad Sci U S A. 1986;83:4913-7.

6. Selkoe DJ. Alzheimer's disease. Cold Spring Harb Perspect Biol. 2011;3(7):a004457.

7. Luchsinger JA, Mayeux R. Dietary factors and Alzheimer's disease. Lancet Neurol. 2004;3(10):579-87.

8. Lue LF, Kuo YM, Roher AE, Brachova L, Shen $Y$, Sue L, et al. Soluble amyloid beta peptide concentration as a predictor of synaptic change in Alzheimer's disease. Am J Pathol. 1999;155:853-62.

9. McLean CA, Cherny RA, Fraser FW, Fuller SJ, Smith MJ, Beyreuther K, et al. Soluble pool of Abeta amyloid as a determinant of severity of neurodegeneration in Alzheimer's disease. Ann Neurol. 1999:46:860-6.

10. Kang J, Lemaire HG, Unterbeck A, Salbaum JM, Masters CL, Grzeschik KH, et al. The precursor of Alzheimer's disease amyloid A4 protein resembles a cell-surface receptor. Nature. 1987;325:733-6.

11. Haass C, Schlossmacher MG, Hung AY, Vigo-Pelfrey C, Mellon A, Ostaszewski $B \mathrm{~L}$, et al. Amyloid beta-peptide is produced by cultured cells during normal metabolism. Nature. 1992;359:322-5.

12. Shoji M, Golde TE, Ghiso J, Cheung TT, Estus S, Shaffer LM, et al. Production of the Alzheimer amyloid beta protein by normal proteolytic processing. Science. 1992;258:126-9.

13. Snyder EM, Nong Y, Almeida CG, Paul S, Moran T, Choi EY, et al. Regulation of NMDA receptor trafficking by amyloid-beta. Nat Neurosci. 2005;8:1051-8.

14. Dewachter I, Filipkowski RK, Priller C, Ris L, Neyton J, Croes S, et al. Deregulation of NMDA-receptor function and down-stream signaling in APP[V717l] transgenic mice. Neurobiol Aging. 2009;30:241-56.

15. Hsieh H, Boehm J, Sato C, Iwatsubo T, Tomita T, Sisodia S, et al. AMPAR removal underlies Abeta-induced synaptic depression and dendritic spine loss. Neuron. 2006:52:831-43.

16. Knobloch M, Mansuy IM. Dendritic spine loss and synaptic alterations in Alzheimer's disease. Mol Neurobiol. 2008;37:73-82.

17. Knobloch M, Farinelli M, Konietzko U, Nitsch RM, Mansuy IM. Abeta oligomer-mediated long-term potentiation impairment involves protein phosphatase 1-dependent mechanisms. J Neurosci. 2007;27:7648-53.

18. Zhang Y, Kurup P, Xu J, Carty N, Fernandez SM, Nygaard HB, et al. Genetic reduction of striatal-enriched tyrosine phosphatase (STEP) reverses cognitive and cellular deficits in an Alzheimer's disease mouse model. Proc Natl Acad Sci U S A. 2010;107:19014-9.

19. Zhao WQ, Santini F, Breese R, Ross D, Zhang XD, Stone DJ, et al. Inhibition of Calcineurinmediated endocytosis and a-Amino-3-hydroxy-5-methyl-4isoxazolepropionic acid (AMPA) receptors prevents amyloid- $\beta$ oligomerinduced synaptic disruption. J Biol Chem. 2010;285:7619-32.

20. Li S, Hong S, Shepardson NE, Walsh DM, Shankar GM, Selkoe D. Soluble oligomers of amyloid $\beta$ protein facilitate hippocampal long-term depression by disrupting neuronal glutamate uptake. Neuron. 2009;62:788-801.

21. Petersen RC. Mild cognitive impairment. N Engl J Med. 2011;364:2227-34.

22. Grundman M, Petersen RC, Ferris $\mathrm{SH}$, et al. Mild cognitive impairment can be distinguished from Alzheimer disease and normal aging for clinical trials. Arch Neurol. 2004;61(1):59-66.

23. Farias ST, Mungas D, Reed BR, Harvey D, DeCarli C. Progression of mild cognitive impairment to dementia in clinic- vs. community-based cohorts. Arch Neurol. 2009;66:1151-7. 
24. Jean $L$, Bergeron ME, Thivierge S, Simard M. Cognitive intervention programs for individuals with mild cognitive impairment: systematic review of the literature. Am J Geriatr Psychiatry. 2010;18:281-96.

25. Lautenschlager NT, Cox KL, Flicker L, et al. Effect of physical activity on cognitive function in older adults at risk for Alzheimer disease: a randomized trial. JAMA. 2008;300:1027-37.

26. Berkmana LF, Glass T, Brissettec I, Seeman TE. From social integration to health: Durkheim in the new millennium. Soc Sci Med. 2000:51:843-57.

27. Wilson RS, Krueger KR, Arnold SE, Schneider JA, Kelly JF, Barnes LL, Tang Y, Bennett DA. Loneliness and risk of Alzheimer disease. Arch Gen Psychiatry. 2007;64(2):234-40

28. Donovan NJ, Okereke OI, Vannini P, Amariglio RE, Rentz DM, Marshall GA, Johnson KA, Sperling RA. Association of Higher Cortical Amyloid Burden with Loneliness in cognitively normal older adults. JAMA Psychiatry. 2016;73: 1230-7.

29. Friedler B, Crapser J, McCullough L. One is the deadliest number: the detrimental effects of social isolation on cerebrovascular diseases and cognition. Acta Neuropathol. 2015;129:493-509.

30. Jiang Z, Cowell RM, Nakazawa K. Convergence of genetic and environmental factors on parvalbumin-positive interneurons in schizophrenia. Front Behav Neurosci. 2013;7:116.

31. Gilman SE, Ni MY, Dunn EC, Breslau J, McLaughlin KA, et al. Contributions of the social environment to first-onset and recurrent mania. Mol Psychiatry. 2015;20:329-36.

32. O'Keefe LM, Doran SJ, Mwilambwe-Tshilobo L, Conti LH, Venna VR, et al. Social isolation after stroke leads to depressive-like behavior and decreased BDNF levels in mice. Behav Brain Res. 2014;260:162-70.

33. Leser $\mathrm{N}$, Wagner $\mathrm{S}$. The effects of acute social isolation on long-term socia recognition. Neurobiol Learn Mem. 2015;124:97-103.

34. Ali AA, Khalil MG, Elariny HA, Abu-Elfotuh K. Study on social isolation as a risk factor in development of Alzheimer's disease in rats. Brain Disord Ther 2017;6:230.

35. Huang H, Wang L, Cao M, Marshall C, Gao J, et al. Isolation housing exacerbates Alzheimer's disease-like pathophysiology in aged APP/PS1 Mice. Int J Neuropsychopharmacol. 2015;18:pyu116.

36. Hsiao $\mathrm{YH}$, Chen PS, Chen SH, Gean PW. The involvement of CDK5 activato p35 in social isolation-triggered onset of early Alzheimer's diseaserelated cognitive deficit in the transgenic mice. Neuropsychopharmacology. 2011; 36:1848-58.

37. Powell ND, Sloan EK, Bailey MT, Arevalo JM, Miller GE, et al. Social stress upregulates inflammatory gene expression in the leukocyte transcriptome via beta-adrenergic induction of myelopoiesis. Proc Natl Acad Sci U S A. 2013; 110:16574-9.

38. Azzinnari D, Sigrist $H$, Staehli S, Palme R, Hildebrandt T, et al. Mouse social stress induces increased fear conditioning, helplessness and fatigue to physical challenge together with markers of altered immune and dopamine function. Neuropharmacology. 2014;85:328-41.

39. Djordjevic A, Adzic M, Djordjevic J, Radojcic MB. Chronic social isolation is related to both upregulation of plasticity genes and initiation of proapoptotic signaling in Wistar rat hippocampus. J Neural Transm (Vienna). 2009;116:1579-89.

40. Murínová J, Hlaváčová N, Chmelová M, Riečanský I. The Evidence for Altered BDNF Expression in the Brain of Rats Reared or Housed in Social Isolation: A Systematic Review. Front Behav Neurosci. 2017;11:101.

41. Liu J, Dietz K, DeLoyht JM, Pedre X, Kelkar D, et al. Impaired adult myelination in the prefrontal cortex of socially isolated mice. Nat Neurosci. 2012;15:1621-3.

42. Li M, Du W, Shao F, Wang W. Cognitive dysfunction and epigenetic alterations of the BDNF gene are induced by social isolation during early adolescence. Behav Brain Res. 2016;15(313):177-83.

43. Bahi A. Hippocampal BDNF overexpression or microR124a silencing reduces anxiety- and autism-like behaviors in rats. Behav Brain Res. 2017;30(326): 281-90.

44. Kumari A, Singh P, Baghel MS, Thakur MK. Social isolation mediated anxiety like behavior is associated with enhanced expression and regulation of BDNF in the female mouse brain. Physiol Behav. 2016;158:34-42.

45. Mikics E, Guirado R, Umemori J, Tóth M, Biró L, Miskolczi C, Balázsfi D, Zelena D, Castrén E, Haller J, Karpova NN. Social learning requires plasticity enhanced by fluoxetine through prefrontal Bdnf-TrkB signaling to limit aggression induced by post-weaning social isolation. Neuropsychopharmacology. 2017; https://doi.org/10.1038/npp.2017.142. [Epub ahead of print]
46. Duzel $\mathrm{E}$, van Praag $\mathrm{H}$, Sendtner M. Can physical exercise in old age improve memory and hippocampal function? Brain. 2016;139:662-73.

47. Grant WB. Using multicountry ecological and observational studies to determine dietary risk factors for Alzheimer's disease. J Am Coll Nutr. 2016; 35:476-89.

48. Gu Y, Luchsinger JA, Stern Y, Scarmeas N. Mediterranean diet, inflammatory and metabolic biomarkers, and risk of Alzheimer's disease. J Alzheimers Dis. 2010;22:483-92.

49. Schiavone S, Sorce S, Dubois-Dauphin M, Jaquet V, Colaianna M, Zotti M, Cuomo V, Trabace L, Krause K-H. Involvement of NOX2 in the development of behavioral and pathologic alterations in isolated rats. Biol Psychiatry. 2009;66:384-92.

50. Khan M, Sekhon B, Jatana M, Giri S, Gilg AG, Sekhon C, Singh I, Singh AK Administration of $\mathrm{N}$-acetylcysteine after focal cerebral ischemia protects brain and reduces inflammation in a rat model of experimental stroke. J Neurosci Res. 2004;76:519-27.

51. Hsiao $\mathrm{YH}$, Chen $\mathrm{SH}$, Gean PW. Amelioration of social isolation-triggered onset of early Alzheimer disease-related cognitive deficit by $\mathrm{N}$-acetylcysteine in a transgenic mouse model. Neurobiol Dis. 2012:45:1111-20.

52. Chan A, Shea TB. Folate deprivation increases presenilin expression, gammasecretase activity, and Abeta levels in murine brain: potentiation by ApoE deficiency and alleviation by dietary S-adenosyl methionine. J Neurochem. 2007;102:753-60.

53. Chan A, Tchantchou F, Rogers EJ, Shea TB. Dietary deficiency increases presenilin expression, gamma-secretase activity, and Abeta levels: potentiation by ApoE genotype and alleviation by S-adenosyl methionine. J Neurochem. 2009;110:831-6.

54. Schinder AF, Poo M. The neurotrophin hypothesis for synaptic plasticity. Trends Neurosci. 2000;23:639-45.

55. Peng S, Wuu J, Mufson EJ, Fahnestock M. Precursor form of brain-derived neurotrophic factor and mature brain-derived neurotrophic factor are decreased in the pre-clinical stages of Alzheimer's disease. J Neurochem. 2005;93:1412-21.

56. Devi L, Ohno M. TrkB reduction exacerbates Alzheimer's disease-like signaling aberrations and memory deficits without affecting $\beta$-amyloidosis in 5XFAD mice. Transl Psychiatry. 2015:5:e562.

57. Chiou YJ, Huang TL. Serum brain-derived neurotrophic factors in Taiwanese patients with drug-nave first-episode major depressive disorder: effects of antidepressants. Int J Neuropsychopharmacol. 2017;20(3):213-8.

58. Phillips HS, Hains JM, Armanini M, Laramee GR, Johnson SA, Winslow JW. BDNF mRNA is decreased in the hippocampus of individuals with Alzheimer's disease. Neuron. 1991;7:695-702.

59. Connor B, Young D, Yan Q, Faull RL, Synek B, Dragunow M. Brainderived neurotrophic factor is reduced in Alzheimer's disease. Brain Res Mol Brain Res. 1997:49:71-81.

60. O'Bryant SE, Hobson V, Hall JR, Waring SC, Chan W, Massman P, Lacritz L, Cullum CM, Diaz-Arrastia R. Texas Alzheimer's research consortium. Brainderived neurotrophic factor levels in Alzheimer's disease. J Alzheimers Dis. 2009:17:337-41.

61. Nagahara AH, Merrill DA, Coppola G, Tsukada S, Schroeder BE, Shaked GM Wang L, Blesch A, Kim A, Conner JM, Rockenstein E, Chao MV, Koo EH, Geschwind D, Masliah E, Chiba AA, Tuszynski MH. Neuroprotective effects of brain-derived neurotrophic factor in rodent and primate models of Alzheimer's disease. Nat Med. 2009;15:331-7.

62. Devi L, Ohno M. 7,8-Dihydroxyflavone, a small-molecule TrkB agonist, reverses memory deficits and BACE1 elevation in a mouse model of Alzheimer's disease. Neuropsychopharmacology. 2012;37:434-44.

63. Zhang Z, Liu X, Schroeder JP, Chan CB, Song M, SP Y, et al. 7,8-Dihydroxyflavone prevents synaptic loss and memory deficits in a mouse model of Alzheimer's disease. Neuropsychopharmacology. 2014;39:638-50.

64. Castello NA, Nguyen MH, Tran JD, Cheng D, Green KN, LaFerla FM. 7,8Dihydroxyflavone, a small molecule TrkB agonist, improves spatial memory and increases thin spine density in a mouse model of Alzheimer disease-like neuronal loss. PLoS One. 2014:9:e91453.

65. Hsiao YH, Hung HC, Chen SH, Gean PW. Social interaction with a helper rescues memory deficit in an animal model of Alzheimer's disease by increasing BDNFdependent hippocampal neurogenesis. J Neurosci. 2014;34:16207-19.

66. Stern Y. Cognitive reserve and Alzheimer disease. Alzheimer Dis Assoc Disord. 2006;20:S69-74.

67. Szekely CA, Breitner JC, Zandi PP. Prevention of Alzheimer's disease. Int Rev Psychiatry. 2007;19:693-706. 
68. Paradise M, Cooper C, Livingston G. Systematic review of the effect of education on survival in Alzheimer's disease. Int Psychogeriatr. 2009;21:25-32

69. Salinas J, Beiser A, Himali JJ, Satizabal CL, Aparicio HJ, Weinstein G, Mateen FJ, Berkman LF, Rosand J, Seshadri S. Associations between social relationship measures, serum brain-derived neurotrophic factor, and risk of stroke and dementia. Alzheimers Dement (N Y). 2017:3:229-37.

70. Branchi I, D'Andrea I, Fiore M, Di Fausto V, Aloe L, Alleva E. Early social enrichment shapes social behavior and nerve growth factor and brainderived neurotrophic factor levels in the adult mouse brain. Biol Psychiatry. 2006:60:690-6.

71. Shors TJ, Townsend DA, Zhao M, Kozorovitskiy Y, Gould E. Neurogenesis may relate to some but not all types of hippocampal-dependent learning. Hippocampus. 2002;12:578-84.

72. Saarelainen $T$, Hendolin P, Lucas G, Koponen E, Sairanen M, MacDonald E, Agerman K, Haapasalo A, Nawa H, Aloyz R, Ernfors P, Castrén E. Activation of the TrkB neurotrophin receptor is induced by antidepressant drugs and is required for antidepressant-induced behavioral effects. J Neurosci. 2003;23: 349-57.

73. Saxe MD, Battaglia F, Wang JW, Malleret G, David DJ, Monckton JE, Garcia $A D$, Sofroniew MV, Kandel ER, Santarelli L, Hen R, Drew MR. Ablation of hippocampal neurogenesis impairs contextual fear conditioning and synaptic plasticity in the dentate gyrus. Proc Natl Acad Sci U S A. 2006;103: 17501-6.

74. Zajac MS, Pang TYC, Wong N, Weinrich B, Leang LSK, Craig JM, Saffery R, Hannan AJ. Wheel running and environmental enrichment differentially modify exon-specific BDNF expression in the hippocampus of wild-type and pre-motor symptomatic male and female Huntington's disease mice. Hippocampus. 2010;20:621-6.

75. Okudan N, Belviranl M. Long-term voluntary exercise prevents post-weaning social isolation-induced cognitive impairment in rats. Neuroscience. 2017; 30(360): 1-8

76. Kronenberg G, Bick-Sander A, Bunk E, Wolf C, Ehninger D, Kempermann G. Physical exercise prevents age-related decline in precursor cell activity in the mouse dentate gyrus. Neurobiol Aging. 2006;27:1505-13.

77. van Praag H, Shubert T, Zhao C, Gage FH. Exercise enhances learning and hippocampal neurogenesis in aged mice. J Neurosci. 2005;25:8680-5.

78. Shors TJ, Miesegaes G, Beylin A, Zhao M, Rydel T, Gould E. Neurogenesis in the adult is involved in the formation of trace memories. Nature. 2001:410: 372-6.

79. Han JH, Kushner SA, Yiu AP, Hsiang HL, Buch T, Waisman A, Bontempi B, Neve RL, Frankland PW, Josselyn SA. Selective erasure of a fear memory. Science. 2009;323:1492-6.

80. Arruda-Carvalho M, Sakaguchi M, Akers KG, Josselyn SA, Frankland PW. Posttraining ablation of adult-generated neurons degrades previously acquired memories. J Neurosci. 2011;31:15113-27.

81. Kim JK, Samaranayake M, Pradhan S. Epigenetic mechanisms in mammals. Cellular and Molecular Life Sciences 2009:66: 596-612.

82. Ptashne M. On the use of the word 'epigenetic'. Current Biology 2007;17: R233-R236.

83. Reik W, Dean W, Walter J. Epigenetic reprogramming in mammalian development. Science. 2001;293:1089-93.

84. Jaenisch R, Bird A. Epigenetic regulation of gene expression: how the genome integrates intrinsic and environmental signals. Nat Genet. 2003;33 ((Suppl):245-54

85. Choudhary C, Kumar C, Gnad F, Nielsen ML, Rehman M, Walther TC, Mann M. Lysine acetylation targets protein complexes and co-regulates major cellular functions. Science. 2009:325:834-40.

86. Eberharter A, Becker PB. Histone acetylation: a switch between repressive and permissive chromatin. Second in review series on chromatin dynamics. EMBO Rep. 2002;3:224-9.

87. Imai S, Armstrong CM, Kaeberlein M, Guarente L. Transcriptional silencing and longevity protein Sir2 is an NAD-dependent histone deacetylase. Nature. 2000;403:795-800.

88. Gräff J, Rei D, Guan JS, Wang WY, Seo J, Hennig KM, Nieland TJ, Fass DM, Kao PF, Kahn M, et al. An epigenetic blockade of cognitive functions in the neurodegenerating brain. Nature. 2012;483:222-6.

89. Guan JS, Haggarty SJ, Giacometti E, Dannenberg JH, Joseph N, Gao J, Nieland TJ, Zhou $Y$, Wang $X$, Mazitschek $R$, et al. HDAC2 negatively regulates memory formation and synaptic plasticity. Nature. 2009;459:55-60.
90. Fischer A, Sananbenesi F, Wang X, Dobbin M, Tsai LH. Recovery of learning and memory is associated with chromatin remodelling. Nature. 2007;447: 178-82.

91. Morris MJ, Mahgoub M, Na ES, Pranav H, Monteggia LM. Loss of histone deacetylase 2 improves working memory and accelerates extinction learning. J Neurosci. 2013;33:6401-11.

92. Neeper SA, Gomez-Pinilla F, Choi J, Cotman CW. Physical activity increases mRNA for brain-derived neurotrophic factor and nerve growth factor in rat brain. Brain Res. 1996:726:49-56.

93. Oliff HS, Berchtold NC, Isackson P, Cotman CW. Exercise induced regulation of brain-derived neurotrophic factor (BDNF) transcripts in the rat hippocampus. Brain Res Mol Brain Res. 1998;61:147-53.

94. Russo-Neustadt A, Beard RC, Cotman CW. Exercise, antidepressant medications, and enhanced brain derived neurotrophic factor expression. Neuropsychopharmacology. 1999:21:679-82.

95. Young D, Lawlor PA, Leone P, Dragunow M. During MJ. Environmental enrichment inhibits spontaneous apoptosis, prevents seizures and is neuroprotective. Nat Med. 1999;5:448-53.

96. Zhao LR, Risedal A, Wojcik A, Hejzlar J, Johansson BB, Kokaia Z. Enriched environment influences brain-derived neurotrophic factor levels in rat forebrain after focal stroke. Neurosci Lett. 2001;305:169-72.

97. Ickes BR, Pham TM, Sanders LA, Albeck DS, Mohammed AH, Granholm AC Long-term environmental enrichment leads to regional increases in neurotrophin levels in rat brain. Exp Neurol. 2000:164:45-52.

98. Aid T, Kazantseva A, Piirsoo M, Palm K, Timmusk T. Mouse and rat BDNF gene structure and expression revisited. J Neurosci Res. 2007;85:525-35.

99. Gomez-Pinilla F, Zhuang Y, Feng J, Ying Z, Fan G. Exercise impacts brainderived neurotrophic factor plasticity by engaging mechanisms of epigenetic regulation. Eur J Neurosci. 2011;33:383-90.

100. Kuzumaki K, Ikegami D, Tamura R, Hareyama N, Imai S, Narita M, Torigoe K, Niikura K, Takeshima H, Ando T, Igarashi K, Kanno J, Ushijima T, Suzuki T, Narita M. Hippocampal epigenetic modification at the brain-derived neurotrophic factor gene induced by an enriched environment. Hippocampus. 2011:21:127-32

101. Holsinger RM, Schnarr J, Henry P, Castelo VT, Fahnestock M. Quantitation of BDNF mRNA in human parietal cortex by competitive reverse transcriptionpolymerase chain reaction: decreased levels in Alzheimer's disease. Brain Res Mol Brain Res. 2000:76:347-54.

102. Wang BY, Zhong Y, Zhao Z, Miao Y. Epigenetic suppression of hippocampal BDNF mediates the memory deficiency induced by amyloid fibrils. Pharmacol Biochem Behav. 2014;126:83-9.

103. Chen KW, Chen L. Epigenetic regulation of BDNF gene during development and diseases. Int J Mol Sci. 2017:18:571.

104. Hsiao YH, Hung HC, YJ Y, CL S, Chen SH, Gean PW. Co-housing reverses memory decline by epigenetic regulation of brain-derived neurotrophic factor expression in an animal model of Alzheimer's disease. Neurobiol Learn Mem. 2017:141:1-8.

105. Yamakawa H, Cheng J, Penney J, Gao F, Rueda R, Wang J, Yamakawa S, Kritskiy O, Gjoneska E, Tsai LH. The transcription factor Sp3 cooperates with HDAC2 to regulate synaptic function and plasticity in neurons. Cell Rep. 2017:20:1319-34.

106. Chao MV. Neurotrophins and their receptors: a convergence point for many signalling pathways. Nat Rev Neurosci. 2003;4:299-309.

107. Francis PT, Palmer AM, Snape M, Wilcock GK. The cholinergic hypothesis of Alzheimer's disease: a review of progress. J Neurol Neurosurg Psychiatry. 1999:66:137-47.

108. Tuszynski MH, Yang JH, Barba D, HS U, Bakay RA, Pay MM, Masliah E, Conne JM, Kobalka P, Roy S, Nagahara AH. Nerve growth factor gene therapy: activation of neuronal responses in alzheimer disease. JAMA Neurol. 2015; 72:1139-47. 